\title{
The absence of diabetic retinopathy in patients with retinitis pigmentosa: implications for pathophysiology and possible treatment
}

\author{
G B Arden
}

Diabetic retinopathy (DR) is a leading cause of blindness but it is not known why retinopathy should be so early and so severe a complication of diabetes. The sensory loss caused by minute retinal lesions is part of the problem, but the diabetic changes in the brain are different and less serious than in the retina, often described as an outpost of the brain. This has led to the concept of a local factor being responsible for the microvasculopathy of DR. There are physiological factors unique to the retina, and it is suggested below how these, by causing hypoxia very early in diabetes, could activate cytokines that produce the microvascular changes. If retinal hypoxia is an important causal factor in the production of DR, prevention of hypoxia should ameliorate DR. This hypothesis predicts that retinitis pigmentosa (RP) should prevent DR. Both old and new work is described, which indicates that this is in fact the case, thus pointing to new, simple, and effective ways of delaying the progress of diabetic retinopathy.

Direct comparison of retinal and brain capillaries taken from diabetics show very considerable differences ${ }^{1}$ (Table 1 ), which indicate a "local factor" in the development of DR. It has been suggested ${ }^{2}$ that the local factor is related to what is unique to the retina, the photoreceptors. The 120 million rods have the highest metabolic rate of any cell in the body. In darkness, the outer limb membrane "leaks", causing an inward "dark current". This current is reduced by light, and at normal photopic levels is shut off completely. In full dark adaptation sodium ions and water enter the outer limb at a maximal rate, and are pumped out in the inner limb. ${ }^{3}$ The entire cytosol volume is pumped in about 15 seconds. ${ }^{4}$ This process requires a great deal of energy and a large oxygen supply. However, the rods are avascular. Despite the "wall" of blood in the choroid and the extensive ramification of the central artery of the retina, oxygen tension $\left(\left[\mathrm{PO}_{2}\right]\right)$ among the unusually large mitochondria of the inner limb is essentially zero. ${ }^{5-7}$ When a flash of light is delivered to the retina, $\left[\mathrm{PO}_{2}\right]$ abruptly rises as the pumps slow down. ${ }^{8}$ Figure 1 shows this effect.

Recent work ${ }^{9-13}$ confirms this result, and also shows that in dark adaptation the receptor layer removes considerable amounts of oxygen from the inner retina so $\left[\mathrm{PO}_{2}\right]$ changes with illumination can also be seen there. ${ }^{14}$ The unusually

Table 1 Differences between retinal and brain capillaries of 10 diabetic and normal dogs. Duration of diabetes: 5 years

\begin{tabular}{lccc}
\hline Abnormality & Retina & Brain & Normal retina \\
\hline Microaneurysms & 43 & 0 & 0 \\
Pericyte ghosts & 25 & 0 & 3 \\
Acellular capillaries & 195 & 0 & 0 \\
$\begin{array}{l}\text { Thickness of basement } \\
\text { membrane (nm) }\end{array}$ & 237 & 171 & 135
\end{tabular}

From Kern and Engermann. ${ }^{1}$ The original contains the statistics and similar data on other dogs made diabetic with galactose. low $\left[\mathrm{PO}_{2}\right]$ would of course affect many other cells adversely. Although some compensatory mechanisms may occur, very small decreases in normal oxygen supply affect retinal function. Thus, dark adaptation is incomplete at reduced air pressures equivalent to heights of only 3000 feetaeroplane cabins are pressurised to 7000 feet-and photopic vision is only affected at about 12000 feet. $^{2}{ }^{15-17}$ Mild unilateral carotid insufficiency causes a unilateral and reversible loss of rod threshold. ${ }^{18} 19$ Polycythaemia vera produces a rheological change in red blood cells that effectively slightly reduces oxygen delivery: and, again, rod threshold increases, reversibly. ${ }^{20}$

Thus, the normal retina in dark adaptation uses so much oxygen that it borders on the pathologically anoxic. There is also evidence that, in diabetics, the retina suffers from oxygen lack before the onset of clinical DR. The electroretinogram becomes abnormal years before funduscopic changes can be seen. ${ }^{21}$ Both (photopic) contrast sensitivity $^{22}$ and colour vision ${ }^{23}$ are impaired even before any microaneurysms are present; and inhaling oxygen from a face mask partially reverses the raised threshold, although the extra oxygen carried to the retina is very small. Scotopic threshold has been known for half a century to be more seriously affected. ${ }^{16}{ }^{24}$ Recent investigations suggest that in mild DR, the threshold initially falls normally, but then recovery ceases, as it would if dark adaptation was occurring in the presence of a dim

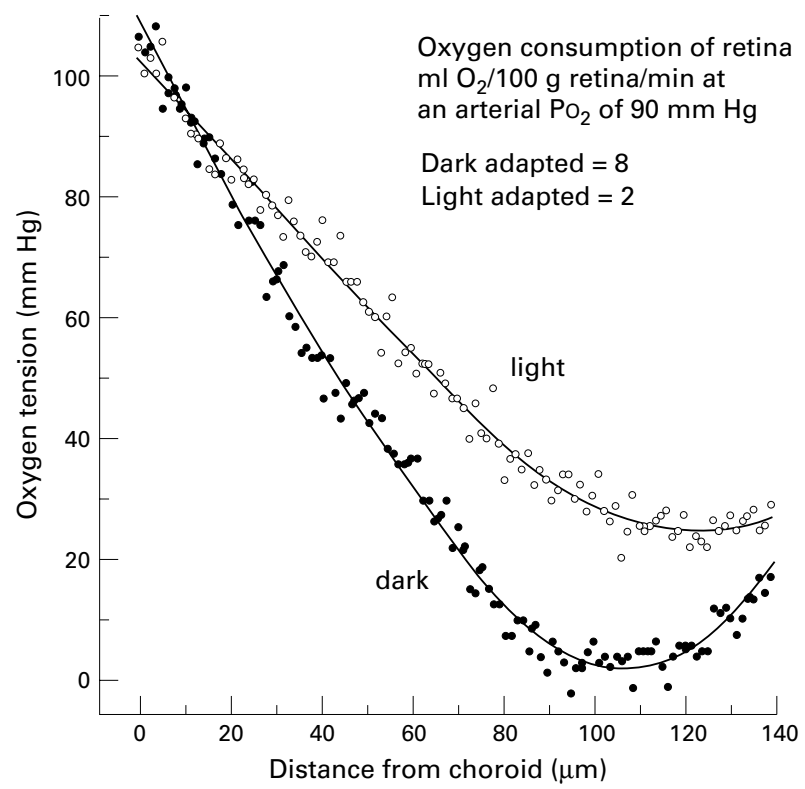

Figure 1 Relation between retinal depth and oxygen tension in darkness and light. Redrawn from refs 5-7. 
background light. ${ }^{17}$ Direct measurement of $\left[\mathrm{PO}_{2}\right]$ in diabetic cat retina has disclosed reductions below the normal even in areas without evident capillary dropout. Thus, it is certain that the diabetic retina rather than being hyperoxic, as is commonly supposed, suffers oxygen lack. ${ }^{25-27}$ All recent work on human retinal blood flow shows that at very early stages of diabetic retinopathy, the circulating blood volume decreases slightly. ${ }^{28-31}$ The vasodilatation that occurs slightly later (in the presence of hyperglycaemia) is quite different. The hypoxia of early diabetic retina is easily explained. The known rheological changes in red blood cells ${ }^{32}$ (similar to polycythaemia vera), the increase in the thickness of capillary basal membranes, ${ }^{1}$ the alteration in the dissociation curve for glycosylated haemoglobin, and the extra demand for oxygen consequent on higher intracellular glucose levels could all cause functional hypoxia. ${ }^{32-35}$

If the early diabetic retina is hypoxic, does this matter? Epidemiological evidence shows that anaemia is (after hyperglycaemia) the greatest risk factor for the development of DR, but the most compelling evidence comes from panretinal photocoagulation (PRP). It was thought that PRP might work by closing leaking vessels and thus preventing the release of vasoformative factors, ${ }^{36}{ }^{37}$ but it now appears that the major cause of the efficiency of the treatment is that it reduces the retinal oxygen need and increases retinal $\left[\mathrm{PO}_{2}\right]$. ${ }^{38}$

How could a decrease in retinal $\left[\mathrm{PO}_{2}\right]$ cause diabetic retinopathy? This question has recently been answered by studies on the cytokine vascular endothelial growth factor (VEGF). VEGF levels increase in diabetic retina. ${ }^{39-42}$ They are enormous in vitreous samples from patients with proliferative $\mathrm{DR},{ }^{43}{ }^{44}$ are related to disease severity ${ }^{45}$ and decrease after successful treatment. ${ }^{46}$ The rise occurs in humans and animals before the development of microvascular changes. ${ }^{47-51}$ Injections of VEGF can produce proliferative retinopathy. VEGF is produced by glia (Müller) cells, which show signs of hyperactivity in early DR at the level of the outer retina, and the receptors for VEGF are located on small vessels in the inner retina. ${ }^{46-54}$ Here VEGF damages endothelial cells and cause leakage. ${ }^{55}$ VEGF is upregulated by hyperglycaemia ${ }^{5156}$ and, very significantly, by hypoxia and the mechanism is such that brief episodes of hypoxia can cause prolonged periods of upregulation. ${ }^{57}$ Mechanisms of action of VEGF have been elucidated. ${ }^{58-63}$ Blockage of VEGF receptors can prevent the retinal neovascularisation and the increased permeability caused by VEGF. ${ }^{64}{ }^{65}$

Thus, a complete chain of evidence implicates VEGF in the causation of DR, and the initial reduction in oxygen supply (in relation to need) could act to initiate the changes which then enter a vicious circle. It is interesting that the nephropathy which accompanies DR is also apparently caused by VEGF acting on glomerular membranes. ${ }^{66}$ Of course this is not to deny the place of other causes of DR (which are outside the scope of this review), but the importance of real anoxia preceding DR, independent of hyperglycaemia, has not previously been highlighted.

A hypothesis which suggests that retinal anoxia is a major underlying cause of DR can be tested. Reduction in retinal metabolism should be associated with a decrease in the development of DR. This is in fact the case. Retinal scars, choroiditis, or advanced glaucoma are all epidemiologically associated with a reduction in DR. Crucially, since rod activity is supposedly responsible for $\mathrm{DR}$, in the absence of rods DR should not occur. Anecdotal evidence of this nature goes back to $1966,{ }^{67-69}$ and in diabetic people who also suffer RP or choroideraemia, the changes of DR never occur (personal communications). However, there is only one recent letter ${ }^{70}$ on this subject, and like the other citations $^{67-69}$ it deals only with proliferative retinopathy. Accordingly, further work was done to better establish the absence of DR in patients with RP.

A large group of inherited degenerative retinal diseases (all called RP) are characterised by an early loss of rod function. Loss of cone vision occurs later, with scotomata, although the function of the fovea is often maintained until middle age. ${ }^{70-73}$ Although the phenotypes are similar, molecular genetic studies have shown a wide variety of basic abnormalities. Thus, more than $30 \%$ of patients with autosomal dominant inheritance have abnormalities in the gene (Rho) coding for rhodopsin. ${ }^{73-76}$ However, mutations in genes coding for other photoreceptor structural proteins and proteins concerned with phototransduction also produce $\mathrm{RP}^{77-87}$ In addition, a number of examples have been reported in which quite different phenotypes can be caused by genetic defects that also cause clinical RP. ${ }^{88} \mathrm{RP}$ is also associated with defects of quite different genes-for example, those concerned with the production of myosin ${ }^{89}$ or the mutations in mitochondrial DNA found in families with maternal inheritance of retinal abnormality (MIDD)..$^{90-93}$

RP and diabetes occur independently. Therefore, although each condition is relatively common, the number of patients with both conditions seen by doctors with large practices is quite small. To identify a relatively large number of patients, advertisements were placed in the internet "chat rooms" of RP patients, and contact made with the websites of patient support groups, requesting patients with both conditions to reply to the author. Some of these were reprinted in braille news sheets. Those replying were sent a brief questionnaire to determine if both diseases were present (Date of birth? Date of diagnosis of diabetes? Do you take insulin? What drugs do you take? At what age were you night blind? What is your vision now? Could you attend a centre to have special photographs of your eyes?). The questionnaire also asked for names and addresses of diabetologists and ophthalmologists who were caring for the patients, and requested permission to approach these people with more detailed questionnaires. The attending doctors were approached to determine the ocular and diabetic status of the patients, even when the patients also gave the details themselves and were informed and definite. The doctors were asked to confirm the type of $\mathrm{RP}$, the date at which the patient became night blind or the field became constricted, the degree of diabetic control, the type of diabetes, and the presence or absence of other diabetic complications. They were asked to provide fundus photographs. The investigation conformed to the Declaration of Helsinki. Ethical approval was obtained locally and from the Foundation Fighting Blindness.

Names and addresses of over 200 patients were received, mostly from the patients' support groups. The largest number, 168, came from the Foundation Fighting Blindness (USA). Sixty seven patients replied to the initial questionnaire. They lived in a number of different countries-USA, New Zealand, Australia, Ireland, France, Germany, Switzerland, and the UK. The proportion of "take up" was lowest for the USA (20\%). This is possibly because the FFB registers have been in existence longest, and patients on the register having moved house more, or have died, grown older, and been unable to respond to written communications.

Of the replies, it was established that seven did not have RP. All these were French (RP is the French acronym for proliferative DR). Of the remainder, two patients' relatives were unwilling to provide further information and some doctors, although repeatedly approached, did not respond. The final results are shown in Table 2 . No patient had any 
Table 2 Details of a survey of patients with diabetes mellitus and retinitis pigmentosa

\begin{tabular}{lll}
\hline Classification of diabetes & IDDM & NIDDM \\
Number of replies validated by doctor & 25 & 30 \\
Mean age (years (SD)) & $60.8(16.8)$ & $65.5(15.3)$ \\
Maximum, median, and minimum ages & $81,61,23$ & $88,67,27$ \\
$\begin{array}{l}\text { Number of cases of diabetic retinopathy } \\
\text { Mean age at diagnosis of diabetes (years) }\end{array}$ & 0 & 0 \\
$\begin{array}{l}\text { Mean duration of diabetes (years) } \\
\text { Interval between night blindness onset }\end{array}$ & 19 & 48 \\
$\quad$ and diabetes onset (years) & $7.2(\mathrm{n}=10)$ & 14.5 \\
$\begin{array}{l}\text { Patients with other non-ocular } \\
\quad \text { complications of diabetes }\end{array}$ & $5(\mathrm{n}=11)$ & $8(\mathrm{n}=18)$ \\
& & \\
\hline
\end{tabular}

DR. In view of the relatively high age of onset in the IDDM group (35 years), the identification of the type of diabetes in some patients is suspect. In some cases, only ophthalmologists replied, and some stated that they did not know if the patients had non-ocular complications of diabetes, or they did not know the details of treatment. However, copies of medical notes and fundus photographs (of varying quality) were also provided in a number of cases. No patient had had the four field standard photographs mandatory for new epidemiological studies and no patient was willing to attend a (remote) centre for such photographs to be taken. Thus the patients' present ophthalmic state is well but not perfectly documented. The reduced number of patients in the last rows of Table 2 reflect the lack of information in the doctors' files about events in their patients' past. Although various types of RP inheritance were represented - autosomal dominant, autosomal recessive, and X linked, as well as Usher's type 1-in only one case had genetic screening been performed. Two cases of Lawrence-Moon-Bartlett-Biedel syndrome are included. The mean age of the patients responding is high, and so therefore is the duration of their diabetes. Since about $40 \%$ of those responding with appropriate information had other diabetic complications, the total absence of any signs of DR is striking. There were no microaneurysms in the sample, no exudates of any type, and no haemorrhages in the retina. Patients were positive that they had never had any retinal abnormalities. Individual histories are illustrative: thus, one patient developed diabetes in early childhood, and 45 years later has no DR, although she has diabetic nephropathy requiring dialysis, and diabetic cardiopathy. Another, aged 78, who developed diabetes aged 5 has no DR. Another, aged 68, with autosomal dominant inheritance reported his night vision became poor 16 years after the onset of diabetes, confirming $^{70}$ the considerable protection against the appearance of DR in patients with RP.

Although the sample is still small, it is double that of all the other reports combined. ${ }^{67-70}$ It is unrepresentative, if only for the age of the respondents, though for the purposes of the investigation the long duration of DM is an advantage. The results completely bear out the belief of ophthalmologists specialising in retinal degenerations that $\mathrm{RP}$ protects against DR and supplement the previous survey of typical $R P,{ }^{70}$ which was concerned only with the presence of proliferative retinopathy. It is reasonably certain that replies were obtained for people with a number of different mutations in different chromosomes.

By making the assumptions (as in Holmes-Walker et $a l^{92}$ ) that previous epidemiological studies ${ }^{94}$ of DR are appropriate for this survey (that is, conservatively, $75 \%$ of patients should have fundal changes of DR 15 years after diagnosis) the probability of obtaining, by chance, a population of 55 cases with RP and no DR is extremely small. The crude binomial probability is $4 / 10000\left(0.75^{27}\right)$. Type II patients may develop diabetes when the retina is relatively non-functional and atrophic. However, in type I, the mean interval between night blindness and the onset of
$\mathrm{DM}$ is only $\sim 7$ years and thus many patients had relatively large areas of partially functioning retina when DM began. In three cases DM developed in childhood, and these patients must have had considerable retinal function and diabetes for more than 10 years. Thus, although the methodology of a retrospective survey is not ideal, it does also highlight the point that these patients have never exhibited evidence of background retinopathy. There are so many genetic changes which cause RP that the only single unifying cause for the protection is the loss of photoreceptors, importantly rods. In many cases of autosomal dominant RP $50 \%$ of rods vanish with an elevation of rod threshold by only $0.3 \log$ unit (due to a loss in the "quantum catch"). ${ }^{2}{ }^{17}$ This degree of night blindness should be as effective as a PRP which "burnt" $50 \%$ of the retina, and illustrates why RP is so protective.

Very occasionally, patients with RP may develop neovascularisation at the optic disc which can regress or develop, but this phenomenon is not understood and the process quite different from DR. ${ }^{96-98}$ Maternally inherited diabetes and deafness (MIDD3243), a mitochondrial disease of adult life, sometimes also causes a pigmentary retinopathy that differs considerably from the more common forms of $\mathrm{RP}$ in which rod loss occurs early. Thus, where electroretinograms (ERGs) have been performed on patients with MIDD, they are abnormal in only 4/13, and rod and cone ERGs are equally affected. In nine of 24 there is either reduced visual acuity or an abnormal visual cortical evoked potential, suggesting earlier macular involvement than in classic RP. Of 24 MIDD cases with $\mathrm{DM}$ and pigmentary retinopathy reported, in two different investigations, five have non-proliferative $\mathrm{DR},{ }^{11-93}$ so they are significantly different $\left(\chi^{2}\right.$ test) from ordinary $\mathrm{RP}$ (Table 2 ). In cases where there is no RP, the incidence of $D R$ is higher, so even incomplete rod loss is partially protective against DR. The cause of MIDD is an abnormality in the reaction centres that produce a proton gradient in the mitochondrion. The variability of the symptomatology is thought to be due to the simultaneous occurrence of normal and affected reaction centres in the same mitochondrion, and the normal/abnormal ratio in different tissues and cells. The way diabetes develops has recently been elucidated..$^{99}$ The fairly frequent occurrence of lesions in photoreceptors is not unexpected in view of the intense metabolic requirements of the inner limb mitochondria.

Comparison of MIDD and the nuclear genetic disturbances may help to discriminate between rival hypotheses $^{217} 70$ of the formation of DR. It has been suggested that an important factor in the production of DR is the production of free radicals. The proposed sequence was that in DM increased glycolysis leads to acidosis and the retina is also hyperoxic. Under such conditions proton gradients induce free radicals, ${ }^{99}$ and these cause DR. The absence of DR in RP was explained by the suggestion that loss of photoreceptors reduced glycolysis and decreased the production of free radicals. In MIDD the basic loss is an inability to make ATP through oxidative phosphorylation and loss of the proton gradient. It is suggested that glycolysis increases. ${ }^{21}{ }^{93}$ If the production of free radicals depends on the establishment of a proton gradient, MIDD might be expected to be protective against DR but this is the case only when retinal degeneration occurs. Thus, the observations on MIDD make the importance of free radicals to DR less likely and are consistent with the anoxia/VEGF hypothesis described here.

In life, dark adaptation and its accompanying low $\left[\mathrm{PO}_{2}\right]$ occurs mostly during sleep. ${ }^{217}$ In turn, this suggests that non-destructive methods of reducing rod dark current could help prevent DR by increasing retinal oxygen tension when it is lowest. ${ }^{100-102}$ The dark current is maintained by 
cyclic guanydyl monophosphate (cGMP), which is destroyed after the absorption of photons. Intracellular calcium accelerates cGMP cyclase and thus the formation of cGMP, but when the pores in the rod outer limb membrane close under the influence of light, calcium entry is reduced and a Na-Ca exchanger greatly reduces $\left[\mathrm{Ca}^{2+}\right]_{\text {in }}$. This is one important mechanism of light adaptation. ${ }^{3}$ Reducing rod guanydyl cyclase activity, or pharmacologically preventing calcium entry, or preventing full dark adaptation by a continuous low level of background light should be an effective form of decreasing peak outer limb retinal oxygen demand. Such interventions could thus slow the progress of diabetic retinopathy. The latter method is simple, inexpensive, and particularly appropriate for the developing world.

Note added at proof stage:

Since this article was submitted it has been shown ${ }^{103}$ that in a group of long term diabetics who do not develop DR, the upregulation of VEGF by anoxia is largely absent, thus lending strong support to the hypothesis developed above.

The author thanks the Foundation Fighting Blindness Inc, the British Retinitis Pigmentosa Society, and Retinitis Pigmentosa International for the facilities offered, and Dr JE Wolf, Dr J Heckenlively, Dr CS Bain, Dr R Tzekov, and Mr
AMP Hamilton, FRCS, for their assistance in contacting patients and for helpful discussions.

G B ARDEN

Applied Vision Research Centre, City University, Northampton Square London EC1V 0HB, UK

g.arden@city.ac.uk

1 Kern TS, Engerman RL. Capillary lesions develop in retina rather than in cerebral cortex in diabetes and experimental galactosaemia. Arch Ophthalmol 1996;114:306-10.

2 Arden GB, Wolf JE, Tsang Y. Does dark adaptation exacerbate diabetic retinopathy? Evidence and a linking hypothesis. Vis Res 1998;38:1723-9.

3 Yau K-W, Baylor DA. Visual transduction. Ann Rev Neurosci 1989;12:289327.

4 Hagins WA, Ross PD, Tate RI, et al. Transduction heats of retinal rods. Tests of the role of cGMP by pyroelectric calorimetry. Proc Natl Acad Sci USA 1989;86:1224-8.

5 Linsenmeier RA. The effect of light and darkness on oxygen distribution and consumption in the cat retina $\mathcal{F}$ Gen Physiol 1986;88:521-42.

6 Linsenmeier RA, Braun RD. Oxygen distribution and consumption in the cat retina during normotension and hypoxaemia f Gen Physiol 1992;99: $177-97$

7 Braun RD, Linsenmeier RA. Oxygen consumption in the inner and outer retina of the cat. Invest Ophthalmol Vis Sci 1995;36:542-54.

8 Haugh LM, Scheidt LA, Griff ER, et al. Light evoked oxygen responses in the toad retina. Exp Eye Res 1995;61:73-81.

9 Ahmed J, Braun RD, Dunn R Jr, et al. Oxygen distribution in the macaque retina. Invest Ophthalmol Vis Sci 1993;34:516-21.

10 Cringle SJ, Yu DY, Alder VA, et al. Quantification of retinal oxygen consumption changes from preretinal oxygen transients. Aust NZ $\mathcal{f}$ Ophthalmol 1997;26:S71-3.

11 Tillis TN, Murray DL, Schmidt GJ, et al. Preretinal oxygen changes in the rabbit under conditions of light and dark. Invest Ophthalmol Vis Sci 1988;29:988-91.

12 Stefansson E. Retinal oxygen tension is higher in light than dark. Pediatr Res 1988;23:5-8.

13 Cringle SJ, Yu D-Y, Alder V, et al. Light and choroidal $\mathrm{PO}_{2}$ modulation of intraretinal oxygen levels in an avascular retina. Invest Ophthalmol Vis Sci 1999;40:2307-13.

14 Haugh LM, Linsenmeier RA, Goldstick TK. Mathematical models of the spatial distribution of retinal oxygen tension and consumption, including changes on illumination. Ann Biomed Eng 1990;18:10-36.

$15 \mathrm{McF}$ arland RA, Evans JN. Dark adaptation and reduced oxygen tension. Am 7 Physiol 1939;127:37-50.

16 Mandlebaum J. Dark adaptation:physiologic and clinical considerations. Arch Ophthalmol 1941;21:203-39.

17 Arden GB, Wolf JE, Collier J, et al. Dark adaptation is impaired in diabetics before photopic visual losses can be seen. Can hypoxia of rods contribute to diabetic retinopathy? In: Hollyfield JG, Anderson RE, LaVail MM, eds. Retinal degenerative diseases and experimental therapy. Proc IIX Int Symp on Retinal Degeneration. New York: Kluwer Academic/Plenum, 1999;Ch 29:305-16.

18 Havelius U, Bergqvist D, Falke P, et al. Impaired dark adaptation in symptomatic carotid artery disease. Neurology 1997;49:1353-9.

19 Havelius U, Bergqvist D, Hindfelt B, et al. Improved dark adapation after carotid endarterectomy. Evidence of a long-term ischaemic penumbra. Neurology 1997;49:1360-4

20 Havelius H, Berglund S, Falke P, et al. Impaired dark adaptation in polycythaemia.

21 Tzekov $\mathrm{R}$ Arden GB. The electroretinogram in diabetic retinopathy Surv Ophthalmol 1999;44:53-60.

22 Harris A, Arendt O, Damnis RP, et al. Hyperoxia improves contrast sensitivity in early diabetic retinopathy. Br f Ophthalmol 1996;80:209-13.

23 Dean FM, Arden GB, Dornhorst A. Partial reversal of protan and tritan colour defects with inhaled oxygen in insulin dependent diabetic subjects. Br f Ophthalmol 1997;81:27-30.
24 Ameniya A. Dark adaptation in diabetics. Ophthalmologica 1977;174:322-6.

25 Linsenmeier RA, Braun RD, McRipley MA, et al. Retinal hypoxia in long term diabetic cats. Invest Ophthalmol Vis Sci 1998;39:1647-58.

26 Alder VA, Yu DY, Cringle SJ, et al. Changes in vitreal oxygen tension distribution in the streptozotocin diabetic rat. Diabetologia 1991;34:469-76.

27 Goldstick TK, Ernest JT, Engerman RL. Retinal oxygen tension in diabetic dogs following insulin infusion. Adv Exp Med Biol 1984;169:661-70.

28 Patel V, Rassam S, Newsom R, et al. Retinal blood flow in diabetic retinopathy. BMf 1992;305:678-83.

29 Bursell SE, Clermont AC, Kinsley BT, et al. Retinal blood flow changes in patients with diabetes mellitus and no diabetic retinopathy. Invest Ophthalmol Vis Sci 1996;37:886-97.

30 Konno S, Feke GT, Yashida A, et al. Retinal blood flow changes in type 1 diabetes. Invest Ophthalmol Vis Sci 1996;37:1140-8.

31 Patel V, Rassam S, Newsom R, et al. Retinal blood flow in diabetic retinopathy. BMF 1992;305:678-83.

32 Ditzel J, Standl E. The oxygen transport system of red blood cells during diabetic ketosis and recovery. Diabetologia $1975 ; 4: 255-60$.

33 Pecvadary Z, Fisher TC, Darwin CH, et al. Deccreased polymorphonuclear leucocyte deformability in NIDDM. Diabetes Care 1994;17:57-63.

34 Enden vd MK, Nyengaard JR, Ostrow E, et al. Elevated glucose levels increase retinal glycolysis and sorbitol pathway metabolism. Invest Ophthalmol Vis Sci 1994:53:2968-75.

35 Tiedman JS, Kirk SE, Beach JM. Inner retinal oxygen consumption increases during hyperglycaemia in diabetic patients. Invest Ophthalmol Vis Sci 1996 ARVO Abs S77 No3569.

36 L'Esperance. Ophthalmic lasers. St Louis: Mosby, 1989.

37 Constable J, Lim ASM. Laser:its clinical uses in eye disease. 2nd ed. PG Publishers 1990.

38 Stefansson E, Hatchell DL, Fisher BL, et al. Panretinal photocoagulation and retinal oxygenation in normal and diabetic cats. Am $f$ Ophthalmol 1986;101:657-64.

39 Aiello LP. Vascular endothelial growth factors. 20th-century mechanisms, 21st-century therapies. Invest Ophthalmol Vis Sci 1997;38:1847-52.

40 Tanihara $\mathrm{H}$, Inatani $\mathrm{M}$, Honda Y. Growth factors and their receptors in the retina and pigment epithelium. Progress in Retinal and Eye Research 1997;16:271-301.

41 Favard C, Ortega N, Bayard F, et al. Vascular endothelial growth factor and retinal neovascularisation:a new approach for diabetic retinopathy. Diabetes Metab 1996;22:268-73.

42 Mathews MK, Merges C, McLeod DS, et al. Vascular endothelial growth factor and vascular permeability changes in human diabetic retinopathy. Invest Ophthalmol Vis Sci 1997;38:2729-41.

43 Aiello LP, Avery RL, Arrig PG, et al. Vascular endothelial growth factor in ocular fluids of patients with diabetic retinopathy and other retinal disorders. N Engl f Med 1994;331:1480-7.

44 Gerhardinger C, Brown LF, Roy S, et al. Expression of vascular endothelial growth factor in the human retina and in nonproliferative diabetic retinopathy. Am f Pathol 1998;152:1453-62.

45 Shinoda K, Ishida S, Kawashima S, et al. Comparison of hepatocyte growth factor and vascular endothelial growth factor in aqueous fluid and serum of patients with various grades of retinopathy in patients with diabetes mellitus. Br F Ophthalmol 1999;83:834-7.

46 Mitzutani M, Gerhardinger C, Lorenzi M. Muller cell changes in human diabetic retinopathy. Diabetes 1998;47:445-9.

47 Murata T, Nakagawa K, Khalil A, et al. The relation between the expression of VEGF and the breakdown of BRB in diabetic rat retinas. Lab Invest 1994;74:819-25

48 Amin RH, Frank RN, Kennedy A, et al. Vascular endothelial growth factor is present in glial cells of the retina and optic nerve of human subjects with nonproliferative diabetic retinopathy. Invest Ophthalmol Vis Sci 1997;38:3647.

49 Gilbert RE, Vranes D, Berka JL, et al. Vascular endothelial growth factor and its receptors in control, and diabetic rat eyes. Lab Invest 1998;78:101727

50 Hammes HP, Lin J, Bretzel RG, et al. Upregulation of the vascular endothelial growth factor/vascular endothelial growth factor receptor system in experimental bakground diabetic retinopathy of the rat. Diabetes 1998;47: 401-6.

51 SegawaY, Shirao Y, Yamagishi S, et al. Upregulation of vascular endothelial growth factor mRNAs in spontaneously diabetic rats without ophthalmoscopic retinopathy. A possible participation of advanced glycation end products in the early phase of diabetic retinopathy. Ophthalmic Res 1998;30:333-9.

52 Boulton M, Foreman D, Williams G, et al. VEGF localisation in diabetic retinopathy. Br f Ophthalmol 1998;82:561-8.

$53 \mathrm{Lu} \mathrm{M}$, Amano S, Miyamoto K, et al. Insulin-induced vascular endothelial growth factor. Invest Ophthalmol Vis Sci 1999;40:3281-6.

54 Smith G, McLeod D, Foreman D, et al. Immunolocalisation of the VEGF receptors FLT-1, KDR, and FLT-4 in diabetic retinopathy. Br 7 Ophthalmol 1999;83:486-94.

55 Antonetti DA, Barber AJ, Khin S, et al. Vascular permeability in experimental diabetes is associated with reduced endothelial occludin content: vascular endothelial growth factor decreases occludin in retinal endothelial cells. Diabetes 1998;47:1953-9.

$56 \mathrm{Lu}$ M, Kuroki M, Amano S, et al. Advanced glycation end products increase vascular endothelial growth factor expression. $\mathcal{F}$ Clin Invest 1998;101;121924.

57 Khalik A, Jarvis D, McLeod D, et al. Oxygen modulates the response of the retinal pigment epithelium to basic fibroblast growth factor and epiderma factor by receptor regulation. Invest Ophthalmol Vis Sci 1996;37:436-43.

58 Behzadian MA, Wang XL, Shabrawey $M$, et al. Effects of hypoxia on glial cell expression of angiogenesis-regulating factors VEGF and TGF-beta. Glia 1998;24:216-25.

59 Duh H, Aiello LP. Vascular endothelial growth factor and diabetes: the agonist versus antagonist paradox. Diabetes 1999;48:1899-906.

60 Aiello LP, Bursell SE, Clermont A, et al. Vascular endothelial growth factorinduced retinal permeability is mediated by protein kinase $\mathrm{C}$ in vivo and suppressed by an orally effective beta-isoform-selective inhibitor. Diabetes 1997:46:1473-80.

$61 \mathrm{Lu} \mathrm{M}$, Perez VL, Ma N, et al. VEGF increases retinal vascular ICAM-1 expression in vivo. Invest Ophthalmol Vis Sci 1999;40:1808-12. 
62 Ellis EA, Guberski DL, Somogyi-Mann M, et al. Increased $\mathrm{H} 2 \mathrm{O} 2$, vascular endothelial grow for endothelial growth factor and receptors in the
betic rat. Free Radic Biol Med 2000;28:91-101.

63 Antonetti DA, Barber AJ, Hollinger LA, et al. Vascular endothelial growth factor induces rapid phosphorylation of tight junction proteins occludin and zonula occludens 1 . A potential mechanism for vascular permeability in diabetic retinopathy and tumors. F Biol Chem 1999;274:23463-7.

64 Ozaki H, Seo MS, Ozaki K, et al. Blockade of vascular endothelial growth factor receptor signalling is suficient to completely prevent retinal neovascularisation. Am $\mathcal{F}$ Pathol 2000;156:697-707.

65 Ferrara N. Molecular and biological properties of vascular endothelial growth factor. F Mol Med 1999;77:527-43.

66 Williams B. A potential role for angiotensin II-induced vascular endothelial growth factor expression in the pathogenesis of diabetic nephropathy. Merv electrolyte Metab 1998;24:400-5.

67 Wetzig PC, Jepson CN. Treatment of diabetic retinopathy by light coagulation. Am ₹ Ophthalmol 1966;62:459-65.

68 Aiello LM, Beetham WP, Balodimos MC, et al. Ruby laser photocoagulation in treatment of diabetic proliferating retinopathy. In: Goldberg MF, Fine SL eds. Treatment of
PHS publication 1890

69 Beetham WP, Aiello LM, Balodimos MC, et al. Ruby laser photocoagulation of early diabetic neovascular retinopathy. Preliminary report of a long-term

70 Sternberg P Jr, Landers MB 3rd, Wolbarsht M. The negative coincidence of retinitis pigmentosa and proliferative diabetic retinopathy. Am f Ophthalmol 1984;97:788-9.

71 Wang MX, Sando RS Jr, Crandall AS, et al. Recent advances in the molecular genetics of retinitis pigmentosa. Curr Opin Ophthalmol 1995;6:1-7.

72 Dryja T. Gene-based approach to human gene-phenotype correlations. Proc Natl Acad Sci USA 1997;94:12117-21.

73 Jurklies B, Zrenner E, Wessing A. Retinitis pigmentosa-clinical, genetic and pathophysiologic aspects. Klin Monatsbl Augenheilkd 1997;210:1-18.

74 Inglehearne CF. Molecular genetics of human retinal dystrophies. Eye 1998;12:571-9.

75 Ponjavic V, Abrahamson M, Andreasson S, et al. A mild phenotype of autosomal dominant retinitis pigmentosa is associated with the rhodopsin mutation Pro-267-Leu. Ophthalmic Genet. 1997;18:63-70.

76 Ponjavic V, Abrahamson M, Andreasson S, et al. Autosomal dominant retinitis pigmentosa with a rhodopsin mutation (Arg-135-Trp). Disease retinitis pigmentosa with a rhodopsin mutation (Arg-135-Trp). Disea

77 Milla E, Heon E, Grounauer PA, et al. Rhodopsin C110Y mutation causes a type 2 autosomal dominant retinitis pigmentosa Ophthalmic Genet 1998;19: 131-9.

78 Bessant DA, Payne AM, Mitton KP, et al. A mutation in NRL is associated with autosomal dominant retinitis pigmentosa. Nat Genet 1999;21:355-6.

79 Inglehearn CF, Tarttelin EE, Plant C, et al. A linkage survey of 20 dominant retinitis pigmentosa families: frequencies of the nine known loci and evidence for further heterogeneity $\mathcal{F}$ Med Genet 1998;35:1-5

80 Huang SH, Pittler SJ, Huang X, et al. Autosomal recessive retinitis pigmentosa caused by mutations in the alpha subunit of rod cGMP phosphodiesterase. Nat Genet 1995;11:468-71

81 Milla E, Heon E, Piguet B, et al. Mutational screening of peripherin/RDS genes, rhodopsin and ROM-1 69 index cases with retinitis pigmentosa and other retinal dystrophies. Klin Monatsbl Augenheilkd 1998;212:305-8.

82 Kucinskas V, Payne AM, Ambrasiene D, et al. Molecular genetic study of autosomal dominant retinitis pigmentosa in Lithuanian patients. Hum Hered 1999;49:71-4.
83 Buraczynska $M$, Wu W, Fujita R, et al. Spectrum of mutations in the RPGR gene that are identified in $20 \%$ of families with X-linked retinitis pigmentosa. Am f Hum Genet 1997;61:1287-92.

84 Fishman GA, Grover S, Jacobson SG, et al. X-linked retinitis pigmentosa in two families with a missense mutation in the RPGR gene and putative change of glycine to valine at codon 60. Ophthalmology 1998;105:2286-96.

85 Zito I, Thiselton DL, Gorin MB, et al. Identification of novel RPGR (retinitis pigmentosa GTPase regulator) mutations in a subset of X-linked retinitis pigmentosa families with the RP3 locus. Hum Genet 1999;105:57-62.

86 Kirschner R, Rosenberg T, Schultz-Heienbrok R, et al. RPGR transcription studies in mouse and human tissues reveal a retina-specific isoform that is disrupted in a patient with X-linked retinitis pigmentosa. Hum Mol Genet disrupted in a p
$1999 ; 8: 1571-8$.

87 Nakazawa M, Wada Y, Tamai M. Arrestin gene mutations in autosomal recessive retinitis pigmentosa. Arch Ophthalmol 1998;116:498-501.

88 Maw MA, Kennedy B, Knight A, et al. Mutation of the gene encoding cellular retinaldehyde-binding protein in autosomal recessive retinitis pigmentosa. Nat Genet 1997;17:198-200.

89 Van Driel MA, Maugeri A, Klevering BJ, et al. ABCR unites what ophthalmologists divide. Ophthalmic Genet 1998;19:117-22.

90 Janecke AR, Meins $M$, Sadeghi $M$, et al. Twelve novel myosin VIIA mutations in 34 patients with Usher syndrome type I: confirmation of genetic heterogeneity. Hum Mutat 1999;13:133-40.

91 Sue CM, Mitchell P, Crimmins DS, et al. Pigmentary retinopathy associated with the mitochondrial DNA 3243. Neurology 1997;49:1013-17.

92 Holmes-Walker DJ, Mitchell P, Boyages SC. Does mitochondrial genome mutation in subjects with maternally inherited diabetes and deafness decrease severity of diabetic retinopathy? Diabetic Med 1998;15:946-52.

93 Smith PR, Bain SC, Good PA, et al. Pigmentary retinal dystrophy and the Alabetes and deafness caused by the mitochondrial DNA 3243 tRNA [Leu] A to G mutation. Adv Exp Med Biol 1999;169:661-70.

94 Klein R, Klein BE, Moss SE, et al. The Wisconsin epidemiological study of diabetic retinopathy III:Prevalence and risk of diabetic retinopathy when age is more than 30 years. Arch Ophthalmol 1984;102:527-32.

95 Mitchell P, Moffit P. Update and implications: the Newcastle diabetic retinopathy study. Aust NZ $\mathcal{f}$ Ophthalmol 1990;19:13-17.

96 To KW, Nadel AJ, Perlstein SH, et al. Bilateral optic disc neovasularisation in association with retinitis pigmentosa. Can f Ophthalmol 1991;26:152-5.

97 Bressler NM, Gragoudas ES. Neovascularisation of the optic disk associated with atypical retinitis pigmentosa. Am f Ophthalmol 1985;100:431-3.

98 Uliss AE, Gregor ZJ, Bird AC. Retinitis pigmentosa and retinal neovascularization. Ophthalmology 1986;93:1599-603.

99 Wolheim CR. Beta-cell mitochondria in the regulation of insulin secretion: a new culprit in type II diabetes. Diabetologia 2000;43:265-77.

100 Stefansson E, Hatchell DL, Fisher BL, et al. Panretinal photocoagulation and retinal oxygenation in normal and diabetic cats. Am $\mathcal{f}$ Ophthalmol 1986;101:657-64.

101 Tillis TN, Murray DL, Schmidt GJ, et al. Preretinal oxygen changes in the rabbit under conditions of light and dark. Invest Ophthalmol Vis $\mathrm{Sci}$ 1988;29:988-91.

102 Stefansson E. Retinal oxygen tension is higher in light than dark. Pediatr Res 1988;23:5-8.1

103 Marsh S, Nakhoul FM, Skorecki K, et al. Hypoxic induction of vascular endothelial growth factor is markedly decreased in diabetic individuals who do not develop retinopathy. Diabetes Care 2000;23;1375-80. 